By RANDOLPH W. CHURCH

\title{
A Library Reorganizes through Building
}

How may a library's internal organization be affected by a building project? One answer is given by the assistant librarian of the Virginia State Library.

$\mathrm{T}$

he Virginia State Library has been in a process of reorganization during the last decade, if such a term can be properly applied to a planned and sustained development over such a period of time. Since, however, all planning was based on adequate quarters and such quarters now have been in use for about three years, this seems a proper time to review accomplishment and to note in what respects occupancy has modified or sustained the original plan.

Any reorganization brought about by a building program is far-reaching, particularly when there is a wide disparity between the old and new quarters. Of necessity a new building is planned for an increased service, and the internal organization which functioned in cramped quarters must be widely changed in its application to larger areas. Relationships between the duties of sections and divisions must be altered, the staff must be expanded, the budget must be materially increased, and even the legal basis of the library's establishment must be explored.

The Virginia State Library is primarily a reference and research institution. It is one of a small group of state libraries that combines under one head the administration of the state's historical collections, both printed and archival; but yet, at the same time, serves as the central public library agency for the state by lending material through individual and interlibrary loan from its central collection and by providing both book collections and financial state aid to public libraries. It is separate from the state law library, though it has always been housed in the same building. Combining as it does the work undertaken in many states by separate agencies, such as state-supported historical societies, state archival establishments, and library commissions, it is able to supervise economically in a related program the library activities of the state. Because of the wide range of its duties, however, its internal organization must be handled and developed with more than an ordinary degree of planning.

In 1934 the Virginia State Library occupied quarters in what was termed a state library building. From the first these had been largely inadequate since the building was not constructed from the modern library standpoint and was designed to house other agencies of state government. Much of the equipment was antiquated or unsuitable and there was no room for expansion. Quarters were badly divided and work was difficult to supervise. Chart A presents graphically the physical 


\section{Chart A}

\section{Old Virginia State Library}

Chart showing relative locations and areas of library quarters. Last figure denotes area in square feet. Letters and figures in ( ) denote floor location.

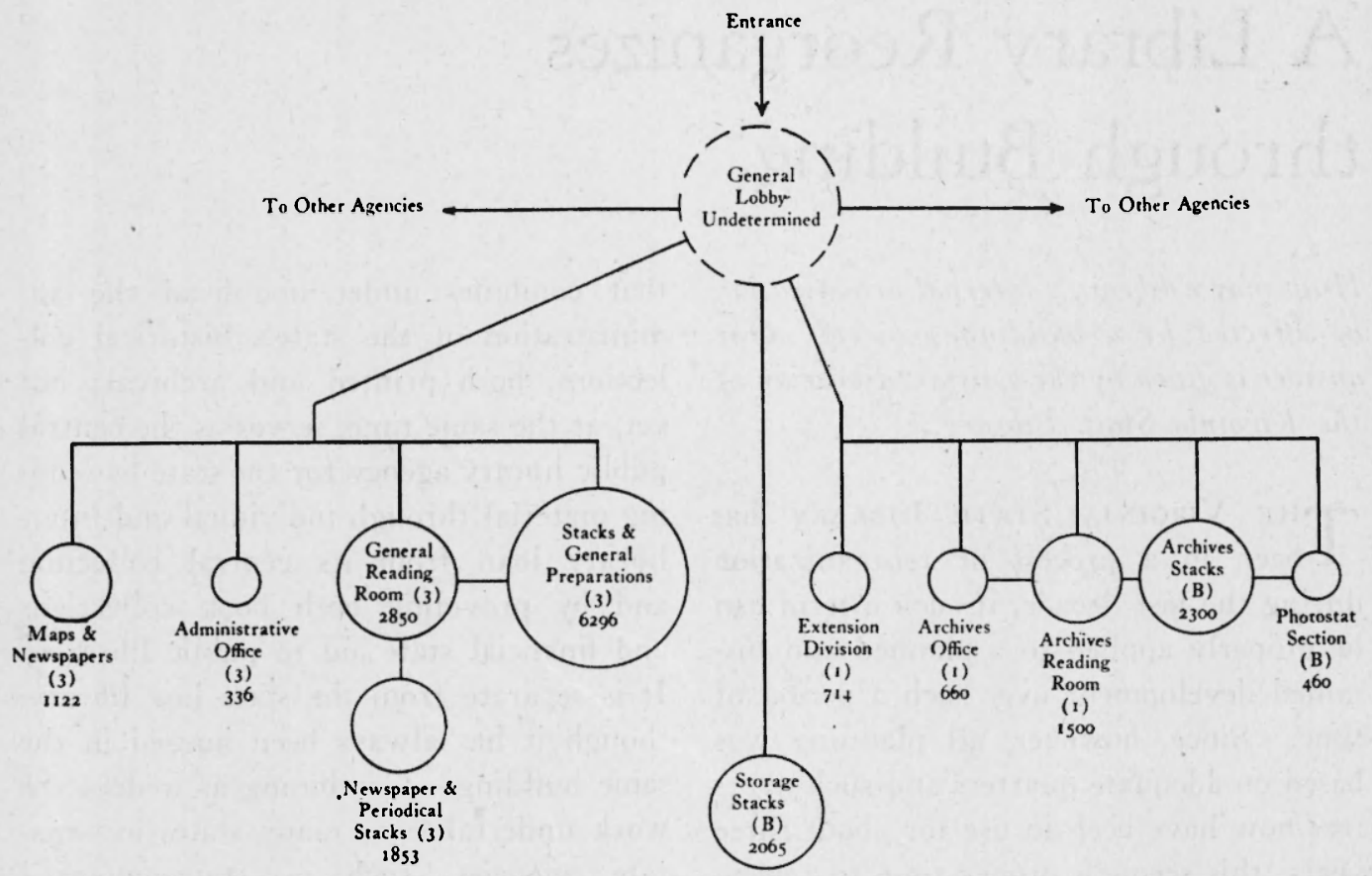

relationships and areas of the various parts of the library at that time. It will be noted that the general library and administrative office were located on the third floor of the building and that the work quarters were within the stacks. The extension division occupied small quarters on the first floor, and an annex housing the archives division and photostat section, with its associated record copyist, was likewise reached from this floor. Separate storage stacks were in the basement. $v$ Communication could be had only through a general lobby. Total floor area of library quarters, counting stacks, comprised 20, I 56 square feet.

At this time the library staff consisted of twenty persons, only four of whom were library school graduates, although a considerable number of the others had

part-time training of one type or another. Routines were greatly compressed. The actual ordering of library material was handled through the librarian's office, where all other correspondence was also cared for, including routines of borrowing by mail and answers to reference questions concerned with both books and archival material, as well as general correspondence and publication work. Checking and cataloging routine, together with supervision of the stacks and reading room, were under the direction of the assistant librarian. Separate checking files were maintained for periodicals, annuals, U.S. documents, and state documents, and actual cataloging was at a minimum. With only three persons to perform it, work on the archival records of the state was largely confined to serving material 


\section{Chart B}

\section{Virginia State Library, 1934}

Chart showing personnel and lines of appointment or responsibility. Library board consisted of five members appointed by state board of education but reporting to governor.

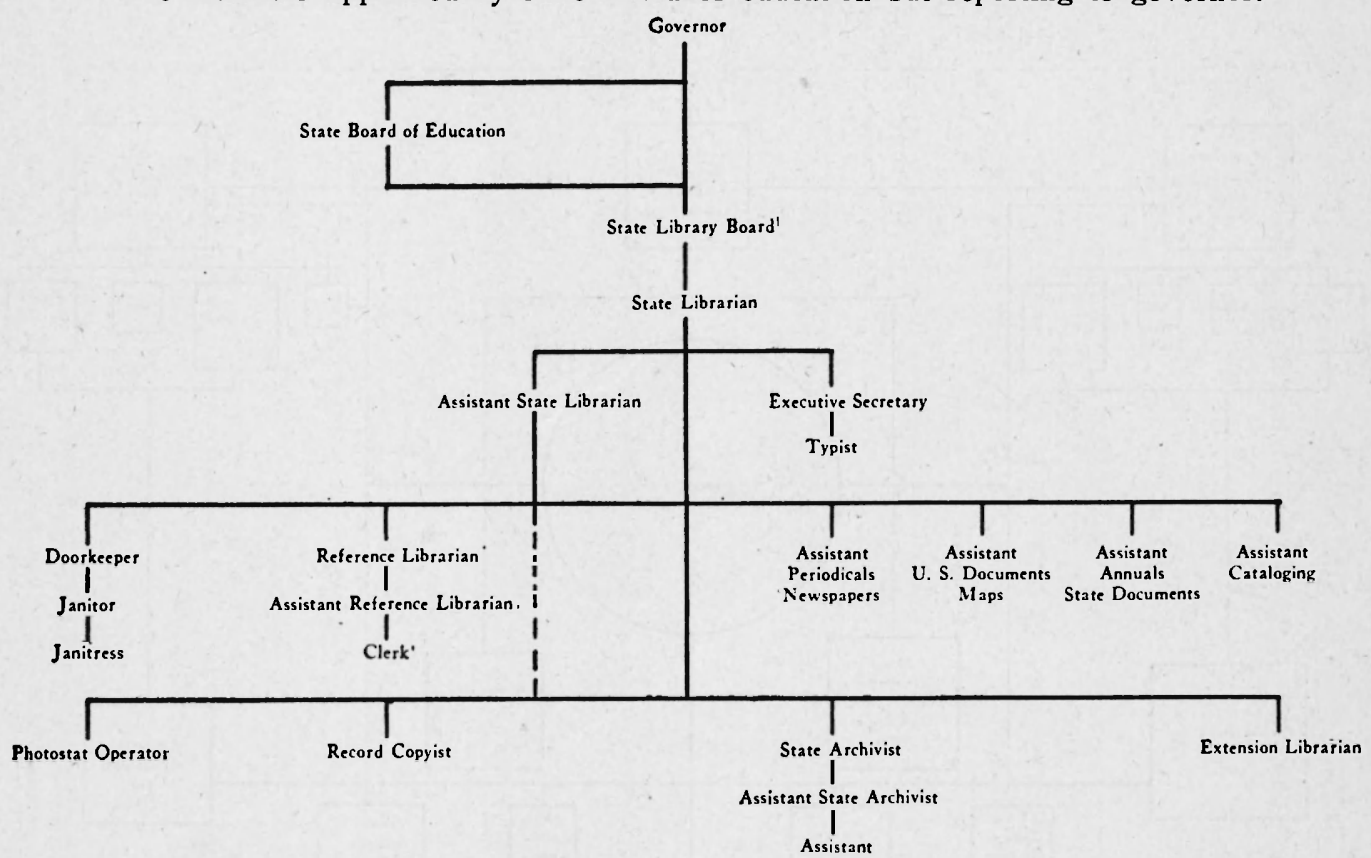

easily available. The copying of public records progressed slowly and extension work was mainly concerned with the acquisition and loan of 'traveling libraries throughout the state. Chart $B$ gives a graphic presentation of the library's internal organization at this period.

The finances of the library were meager, with a total appropriation for ordinary services of only $\$ 46,220$, broken down as follows:

Expenses of operation, including salaries, communication, replacements, etc.

Administration

General library

$\$ 7,330$ I6,905

Archives division, including photostat division and record copyist I I,295

Extension division

2,975

Capital outlay for all divisions, books, binding, publications, etc.

7,715

$\$ 46,220$
Under such conditions it was obvious to the authorities of the library that the work of the institution had reached a critical point, where further progress could not be made without new quarters and a new organization. To be sure, efforts had been made before towards a new building, which at one time had seemed assured, but it remained for this period to see the work energetically pushed to a conclusion.

In 1936 the general assembly appointed a building commission to investigate the question and to secure as a gift from the City of Richmond the necessary ground for the structure. This was accomplished in March 1938 and resulted in an appropriation from the general assembly of that year of funds sufficient to ensure the project with federal aid. During this period the librarians prepared a list of requirements for the building, together 


\section{Chart C}

\section{Proposed Virginia State Library}

Chart showing relative locations and areas of library quarters. Last figure denotes area in square feet.

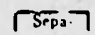

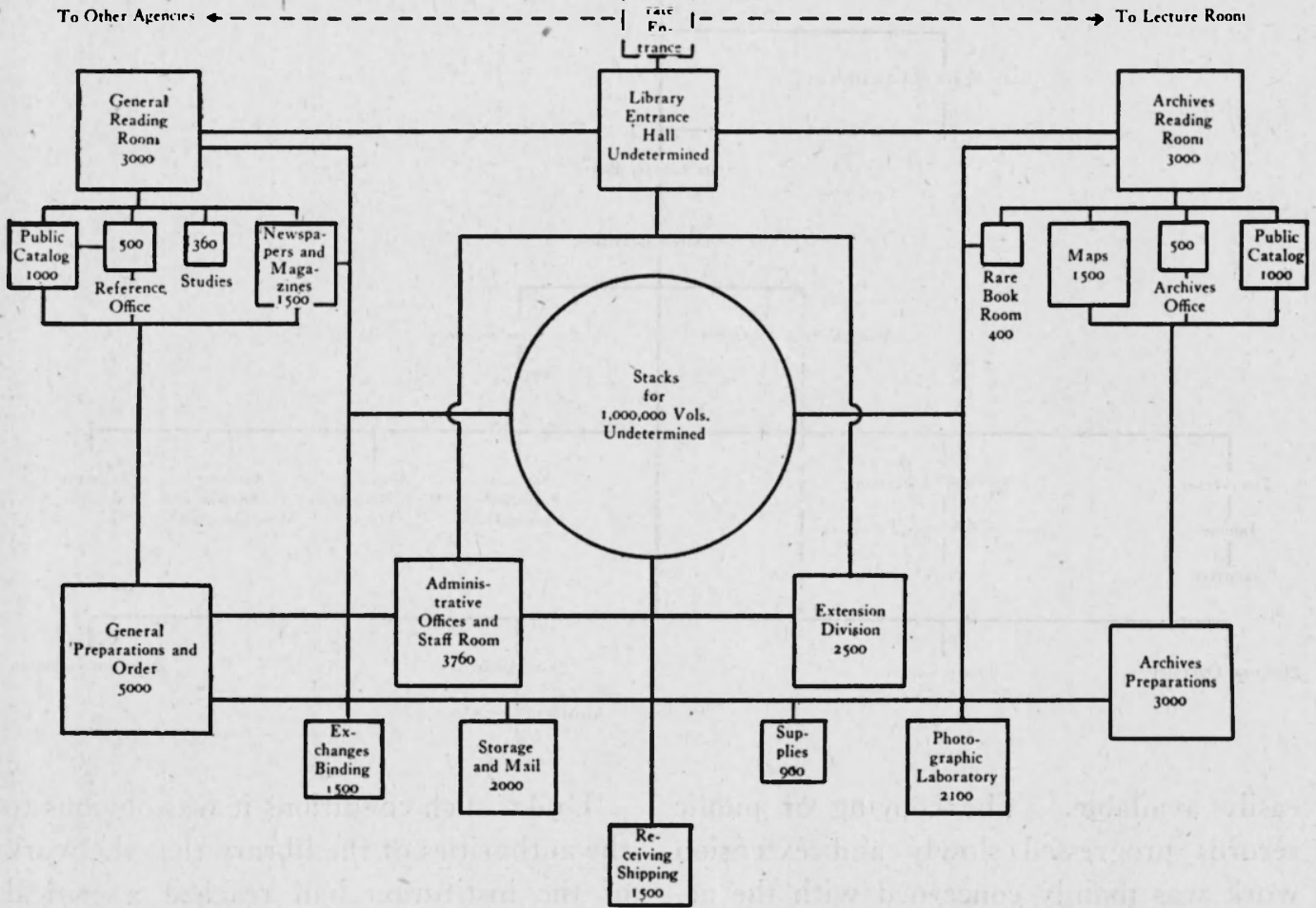

with a chart showing the desired relative locations and areas of library quarters, which is here reproduced as Chart C. Ground was broken on Dec. 7, 1938, and the building was opened for use on Dec.

general. Their quarters, however, were distinct from those of the state library and approached by a separate entrance, the building being in reality two buildings in one. Total floor area provided for the 23, 1940. It was a source of the greatest $/$ library quarters was I I 5,492 square feet, satisfaction on the part of the librarians that the architects were able to translate their requirements into a suitable structure. Chart $\mathrm{D}$, showing the actual relative locations and areas of the building as finally constructed, may be profitably compared with Chart C, the librarians' plan, to show how nearly alike they are. It will be seen from these that the new building $v$ was designed to house some other agencies ihan the library, viz., the supreme court, the state law library, and the attorney an increase of 473 per cent over the old quarters.

In considering the relationships of the various divisions and sections within new quarters, certain fundamental changes in the library's organization were determined. It was found that the work of the library fell naturally into five groups, i.e., administration, general library, archives, extension, and publication. In the old quarters there was no clear line of demarcation between these activities and no 


\section{CharT D}

New Virginia State Library

Chart showing relative locations and areas of library quarters. Last figure denotes area in square feet. Letters and figures in ( ) denote floor location.

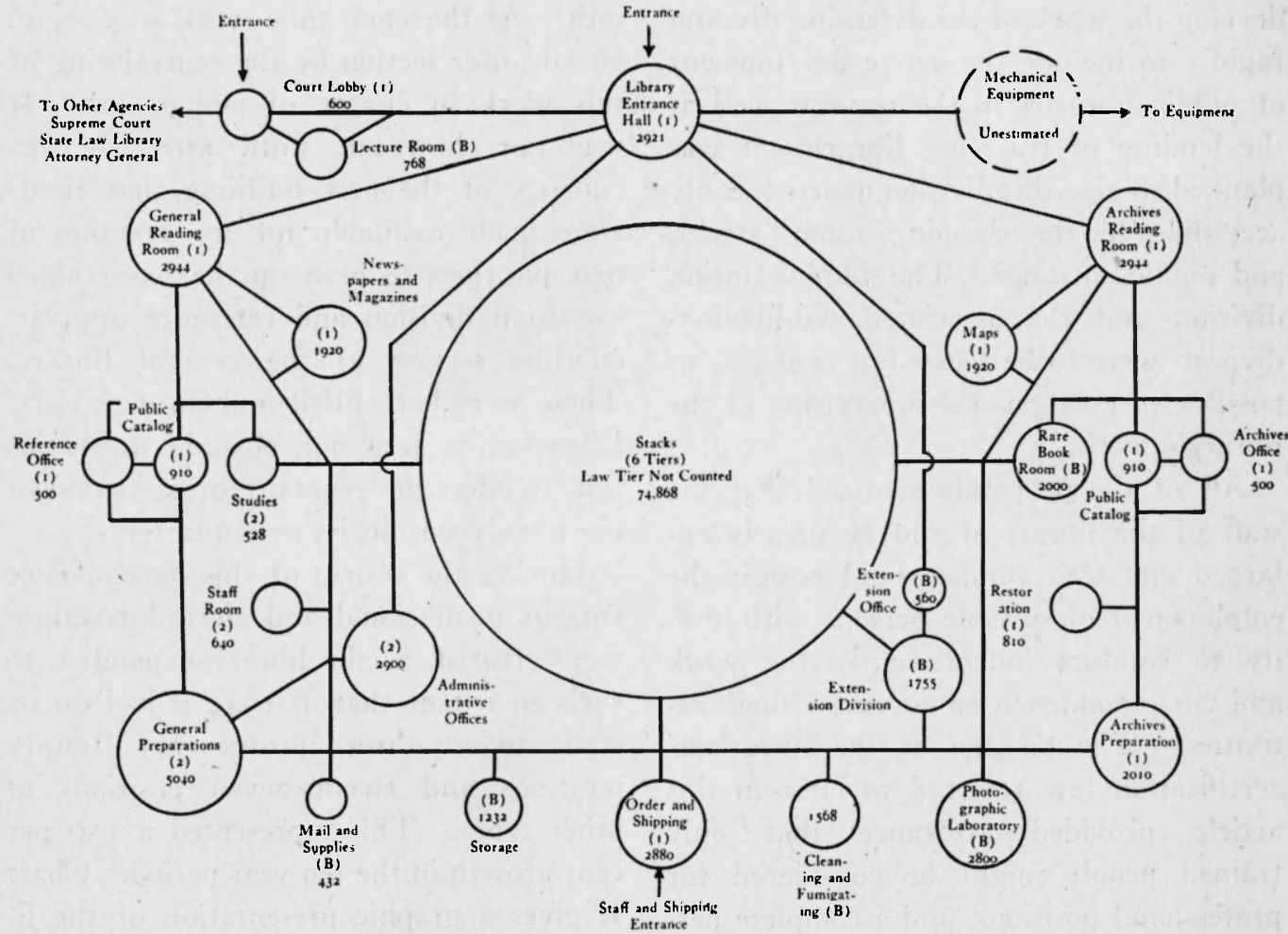

unification of related work. In planning the new building, such unity was highly desirable. To this end it was proposed that the reference activities of the library be confined, as far as possible, to the first floor of the building and grouped around a general reference section and archives division. Under general reference, a section of the general library division, was to fall the administration of the general reading room, the newspaper and periodical room, and the study cubicles, as well as the supervision of individual and interlibrary loans. $\vee$ Under the archives division was to fall the preparation and service of both archival material and printed and manuscript maps. In addition it was felt, since most of the work of photoduplication was concerned with manuscript and archival material, that an expanded program, including full microphotography, should be under the direction of the archives division. ' It was further proposed that the rare book collection should be housed in conjunction with it and serviced under its supervision. ${ }^{1}$ Since the other work of the general library division, concerned with the acquisition and processing of printed material, could be broken up into several natural groups, it was determined to establish an order section to serve all divisions

${ }^{1}$ A full discussion of the suitability of an archival agency administering such material as maps and rare books may be found in the writer's article "The Relationship between Archival Agencies and Libraries." American Archivist 6:145-50, July I943. 
and conduct exchanges, a serials section with visible file equipment for a consolidated serials record, including binding, and a catalog section, all as closely related as possible. Since it was contemplated to develop the work of the extension division rapidly to include the active development of public libraries in the state as well as the lending of traveling libraries, it was planned to give this division quarters easily accessible to the shipping room, stacks, and public entrance. The administration division and the associated publications division were to be located as centrally as possible to give general supervision of the library's work.

All of the proposals assumed that the staff of the library would be greatly enlarged and that funds would permit the employment of suitable persons with ability to conduct independently the work and correspondence, to supervise these activities. The passage of the librarians' certification law referred to later in this article provided assurance that only trained people might be considered for professional positions, and a complete personnel survey of state employees in 1937 created the opportunity of having library positions carefully considered as to their proper grade and salary.

\section{Reorganization}

With the physical relationships of quarters in the new building established and with a general program for the enlargement of the staff determined, reorganization was begun in terms of the contemplated building. In October $\mathrm{r} 938$ a catalog section was organized in the general library division, with a head cataloger in charge. In January 1939 the archives division, photostat division, and record copyist were brought together un- der one direction by the appointment of a head archivist. In July of the same year a head of a new serials section was appointed and various scattered files were brought together in one new visible file unit. At the same time work was begun on an order section by the centralizing of this work in charge of one person. It was not, however, until after the occupancy of the new building that funds were made available for the creation of new positions to head up the reorganized extension division and reference and circulation section of the general library. These were both filled in February 194I. Likewise, it was not possible until this time to effect the general reorganization of the library within its new quarters.

During the course of this development various professional and clerical positions were created, as the library expanded, to such an extent that in 1944 it had on its staff twenty-three professional library positions and twenty-seven positions of other types. This represented a I 50 per cent growth in the ten-year period. Chart $\mathrm{E}$ gives a graphic presentation of the library's staff organization at the present time and may be compared with Chart B to note the changes made in the period.

In 1944 the library budget provided a total of $\$ \mathrm{I} 69,955$ as against the $\$ 46,220$ of 1934 , a 267 per cent increase. This was broken down as follows:

Expenses of operation, including salaries, communication, replacements, etc.

Administration

General library

\$ 14,885

Archives division

42,355

22,520

Extension division

12,195

Capital outlay for all divisions,

books, binding, publications, etc. State aid for public libraries

28,000 50,000

$\$ 169,955$ 


\section{Chart E}

\section{Virginia State Library, 1944}

Chart showing personnel and lines of appointment or responsibility. Library board consists of seven members appointed by and responsible to the governor including the superintendent of public instruction ex officio. Roman numerals indicate grades of professional positions.

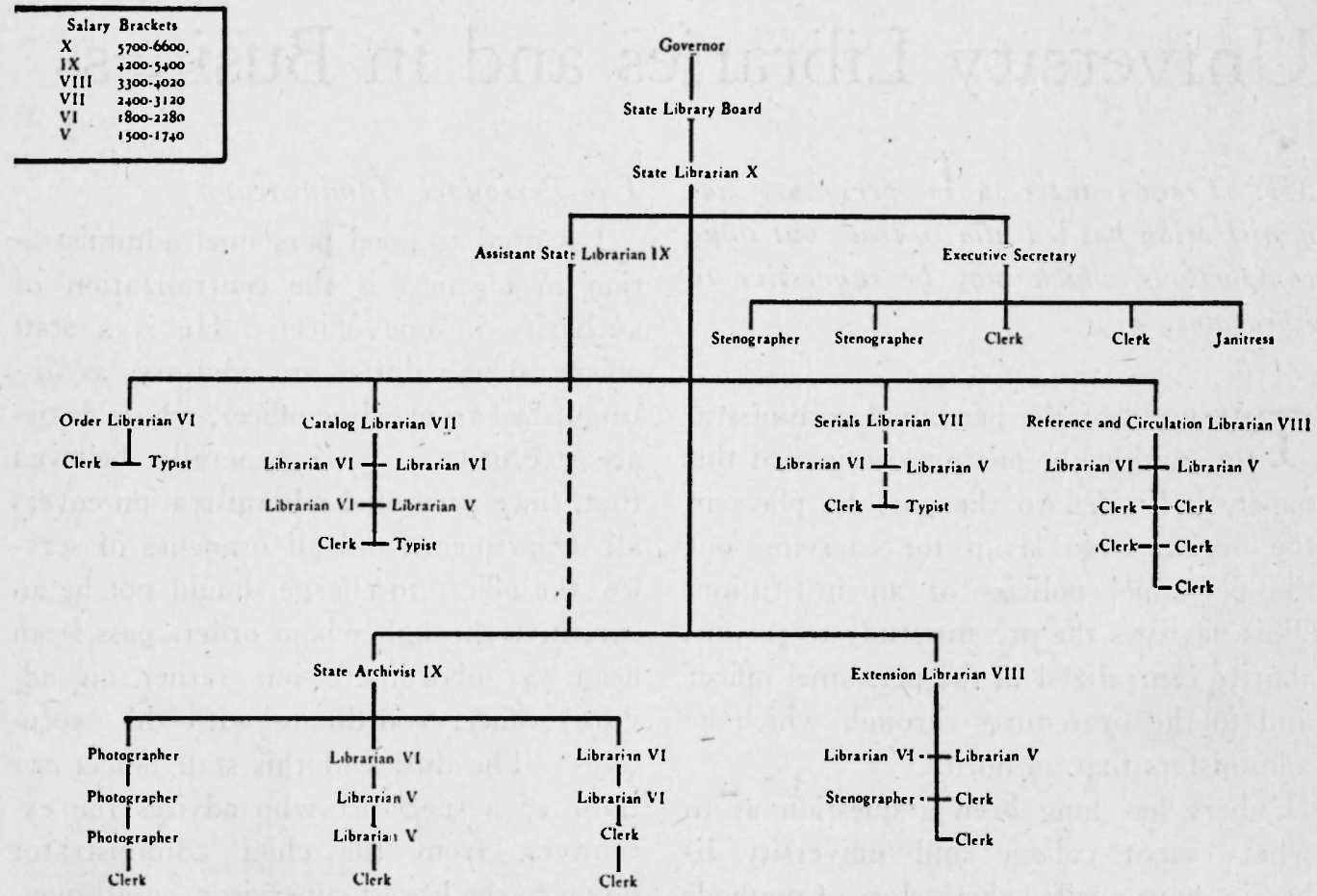

In 1936, under the sponsorship of the Virginia Library Association, the library laws of the state were amended and codified. Many of these dealt directly or indirectly with the activities of the state library. Provisions concerning the copying of public records were enlarged and the state library was authorized to secure copies of state publications for exchange purposes. A state board for the certification of librarians was established, with the state librarian as secretary, and all libraries operated by the state or under its authority, with few exceptions, were required to employ in professional positions only persons with librarians' certificates. The law concerning establishment of county libraries was enlarged so as to al- low establishment of both. county and regional libraries under various forms and contracts, and this law was further modified at later sessions for better operation. In 1940 laws concerning the destruction of public records and the admissibility of microphotographs as official copies were passed. In 1942 the state library was given $\$ 50,000$ a year for state aid to public libraries under a special bill, and in 1944 a general law concerning state aid was passed and the same sum set up in the budget for the state library's use. This last session also provided for the reestablishment of the state library board, with seven instead of five members, appointed by the governor rather than the (Continued on page 334) 
U.S. Office of War Information, the British Information Services, and Fighting France. These exhibits are changed on the first and fifteenth of every month. Some of the subjects emphasized have been economics of peace and war, health, recreation, postwar planning, and the Netherlands, the last named being a timely exhibit arranged for Princess Juliana's recent visit.

A collection of Russian periodicals and publications of learned societies, outstanding in the West, has enabled the library to provide the results of research by the Russians on synthetic rubber and on surgery at the front and, curiously enough, articles on their discoveries relating to tropical medicine.

One very practical request was for descriptions in German and Russian of antiaircraft guns. As part of the lend-lease program, a merchant ship from Russia was being equipped with guns of this type. The men responsible for their care and operation knew no English, so that it was necessary for us to assemble articles published in Russian and German, with which they were familiar. Two Russian sailors, with an interpreter, came to the library for the references which we had selected and also for technical dictionaries. When the materials were returned, the interpreter expressed the gratitude of the Russians, who smiled and nodded approval.

Some account of the war work of the Reference Division of the University of California Library has been given by suggesting the variety and importance of the reference questions. The actual work involved has been a highly stimulating experience to the members of the staff. They have had a sense of rich reward in the realization of an active participation in the war effort. The future holds the responsibility of serving in unpredictable ways the personnel already concentrating with determined purpose in this key area adjacent to the Pacific theatres of war.

\section{A Library Reorganizes through Building \\ (Continued from page 32I)}

state board of education. It provided, however, that the superintendent of public instruction would be included as an ex officio member of the board and that the state library was to be the administrative center for state public library development.

As with any developing institution, the reorganization of the state library is as yet incomplete. The goal set for a complete service in the new building as of r94I included a staff of thirty-two professional and thirty-one positions of other character and a budget of at least $\$ 200,000$. These have not yet been achieved, although substantial progress has been made. A comparison of advances made in the decade, however, show very definite, sustained improvement, and the prospects of the library's reaching a period of ever-increasing usefulness to the commonwealth are, even now, encouraging.

In conclusion it may be said that the library has been extremely fortunate in having been able to make a planned reorganization for a new building rather than having been faced with a sudden reorganization in unplanned quarters. Occupancy of the building has modified in no major respect the routine and organization that were determined at the beginning. 